\title{
A Quantitative Approach to Characterizing the Changes and Managing Urban Form for Sustaining the Suburb of a Mega-Urban Region: The Case of North Cianjur
}

\author{
Anoraga Jatayu ${ }^{1, *}$, Ernan Rustiadi ${ }^{1,2, *}$ and Didit Okta Pribadi $2,3, *$ (D) \\ 1 Regional Planning Study Program, Department of Soil Science and Land Resource Management, \\ Faculty of Agriculture, IPB University, Bogor 16680, Indonesia \\ 2 Center for Regional Systems, Analysis, Planning and Development (CRESTPENT), IPB University (IPB), \\ Jl. Raya Pajajaran, Bogor 16114, Indonesia \\ 3 Research Center for Plant Conservation and Botanic Garden, Indonesian Institute of Science, \\ Jl. Ir. H. Juanda No. 13, Bogor 16122, Indonesia \\ * Correspondence: anoragajatayu@apps.ipb.ac.id (A.J.); ernan@indo.net.id (E.R.); \\ diditpribadi@yahoo.com (D.O.P.)
}

Received: 25 August 2020; Accepted: 26 September 2020; Published: 30 September 2020

check for updates

\begin{abstract}
Mega-urban development in Monsoon Asia has a relatively similar pattern, which leads to the formation of Mega-Urban Region (MUR). Such urban development potentially threatens sustainability as it vastly expands to encroaching rural areas. North Cianjur has been experiencing urban expansion from its surrounding metropolitan areas of Jakarta and Bandung that leads to the formation of urban sprawl and many other environmental problems. In this case, spatial characterization based on a quantitative and objective approach is urgently needed to provide better insight into the development of the mega-urban region's suburb. This study proposed a quantitative and objective approach which was developed based on a quantitative zoning method. This study aims to characterize the region affected by urban expansion and urban form dynamics in North Cianjur using spatial clustering and spatial metrics approaches. The results showed that North Cianjur has four different zones consisting of two urban zones, a peri-urban zone, and a rural zone. Furthermore, the dynamics of urban forms in North Cianjur showed a trend of a more compact form in the urban zones while outside the urban zones it has become more sprawled and dispersed. This implies that spatial planning policies are incapable of containing and managing the massive expansion forces which were coming from Jakarta metropolitan, Bandung metropolitan, as well as Cianjur urban zones itself. Thus, the quantitative zoning method could enhance spatial planning, as different zones of urban-rural typology and urban from in the mega-urban suburb can be defined as a base for developing more specific effort in managing land-use changes. This approach could be adopted by other regions which have similar characteristics.
\end{abstract}

Keywords: Rustiadi's quantitative zoning method; spatial clustering; spatial metrics; urban form; regional typology

\section{Introduction}

Mega-urban region development in developing countries, especially in Monsoon Asia, has a relatively similar pattern characterized by the expansion of urban land use to their surrounding areas to form the Extended Metropolitan Regions (EMR) [1]. Further expansion of the EMR sometimes has collided with the adjacent EMR to form a bigger urban conurbation called the Mega-Urban Region 
(MUR), where Megalopolis/MUR refers to continuous urbanized areas that connect metropolitan centers [2]. The growth of the region was also characterized by increased economic activity in multiple sectors; connectivity between metropolitan, cities, large towns, peri-urban and rural areas; and significant land-use changes [3]. Several main causes of urban expansion are population growth, industrialization, urbanization, transportation network development, and government policies [4-6].

The urbanization process is able to create an enormous continuous urban area, which result in various problems of urban infrastructure management, land-use conflicts, and environmental degradation [1]. When it keeps continuing, it will drive the conversion of agricultural land in rural areas due to urban sprawl [7]. An urban sprawl which is characterized by leapfrog and/or dispersed pattern of urban expansion indicates the changes of urban form that lead towards "chaotic land-use" [8]. Such type of land-use pattern is inefficient, unsustainable, and hard to manage [8,9].

Urban form is the physical characteristics that form a region with several indicators such as shape, size, density, and configuration of various types of land use in it. The spatial pattern of land use as a result of the urbanization process is able to portray the urban form of a region. Land use phenomena such as sprawl, urban corridor, compact city, and various other forms are the implementation of the urban form concept in spatial planning, which also has a major influence on regional development [10]. Urban form needs to be considered in zoning and planning of urban and metropolitan areas, as well as in its hinterland and the suburban regions, to avoid sprawl or uncontrolled development [11]. The urban form dimension is also able to identify economic influences and other socio-ecological factors, so that it can be considered as an indicator of regional sustainability [12].

The Mega-Urban regions have very high dynamic growth and developments due to the urbanization and suburbanization process. Therefore, a comprehensive and robust approach is necessary to respond to the various demand for regional developments. Moreover, urbanization also occurs as a response to the lack of control and evaluation in the implementation of the spatial plan. As a spatial plan is mainly arranged based on top-down and/or consensus-qualitative approaches, especially in developing countries, the planning result will be biased by a lot of subjectivities and often cannot meet the needs of the people as well as the characteristics of the region itself. An objective zoning approach is needed to provide a more precise and accurate picture of the trend of changes in spatial patterns. In this case, a quantitative zoning approach based on an analysis of spatial pattern characteristics is expected to provide additional insight in making spatial planning decisions [13,14]. The quantitative zoning approach that would be developed in this research will also contribute to enhancing spatial planning systems by giving more empiric and objective spatial characterization [13]. Implementation and the development of a quantitative algorithm will offer opportunity for being applied over time and over regions.

The urbanization process in Jabodetabekpunjur begins with urban agglomeration within the core Jakarta and its surrounding inner rings (Depok, Bogor, and Tangerang). Then, it is further expanded to its outer ring (Bogor and Cianjur), resulting in the transformation from a single-core into a multi-core metropolis [15]. This growth also causes the transformation of its hinterland to urban fringes [16]. The most prominent expansion happens in two corridors, the Bekasi corridor (northern expansion corridor) and Cianjur corridor (southern expansion corridor). A similar expansion also happens in Bandung Metropolitan Area, where the two metropolises showed a conurbation trend forming Jakarta-Bandung Mega-Urban Region (JBMUR) [2].

The North Cianjur Region is a part of Cianjur regency which is located between two of Indonesia's biggest metropolitan areas called Jakarta Metropolitan Area (JMA) and Bandung Metropolitan Area (BMA). These two metropolitans show a trend of conurbation and it was predicted that they would merge into Jakarta-Bandung Mega-Urban Region (JBMUR) [2]. Therefore, the position of North Cianjur as a hinterland or buffer area of both metropolitan areas has become important to maintain environmental sustainability, as well as to serve as one of the important urban corridors.

Recently, the Indonesian government has established the Jakarta Metropolitan Area spatial plan that designates Cianjur regency as a largely rural area with little urban activities to maintain environmental 
balances of heavily urbanized areas of Jakarta [17-19]. Contrarily, the Cianjur Regency and West Java Spatial Plan have facilitated North Cianjur (especially Puncak-Cipanas urban center) to grow as an urban area $[20,21]$. Sustainability issues in North Cianjur have emerged due to the asynchronous spatial planning policies from different planning hierarchy. The rapid growth of the JBMUR region towards its hinterland has led to accelerated development in the North Cianjur region which then increases inequality between the north and south area of Cianjur regency. Imbalanced spatial development might cause sustainability issues, such as long-term impacts on the regional economy, infrastructure provision, population distribution, environmental issue, and urban-rural linkages [22-24]. The flawed planning process coupled with urban expansion in JBMUR have made the existing spatial planning policy fail to manage urban growth, meaning that the future development of this regency will face bigger threats to its sustainability.

Research regarding spatial characterization has often focused on exploring either physical aspects [25-27] or socio-economic aspects [28-30] of urban expansion. This research aims to combine both as variables which are considered in the quantitative zoning approach, and to use this method to address difficultuies in managing the highly dynamic development of a mega-urban suburb. In this research, we aim to characterize the region affected by urban expansion, which is North Cianjur, based on regional typology and urban form analysis. Then, we aim to define how the planning policy in Cianjur regency is affected and/or affecting this phenomenon. Using remotely sensed data, spatial clustering, and spatial metric, we investigated urban expansion in the North Cianjur region based on time-series data from 2004-2019.

\section{Materials and Methods}

\subsection{Study Area}

Urbanization, especially in the mega-urban region, has led to urban expansion towards its hinterland [31,32]. This trend was especially prominent in Monsoon Asia [6], exhibiting the emergence of the "desakota" region, an in-between characteristic of urban and rural areas [1,3]. Studies in several regions in Monsoon Asia showed that Bangkok and Ho Chi Minh mega-urban regions [31] have a top-down spatial plan that not only cover the city but also their hinterland. In another example, studies on the Seoul and Tokyo mega-urban regions [33-35] show that administrative boundaries are less considered in managing mega-urban regions, but more emphasis is given to the nature of the dynamics of those regions. The Jakarta-Bandung mega-urban region, however, seems still to struggle with finding the optimal approach in its planning and governance $[15,16,36,37]$.

The study area of this paper is located in the northern part of Cianjur regency which is adjacent to Jakarta Metropolitan Area to the northwest and Bandung metropolitan area to the east (Figure 1). The population of Cianjur in 2004 was 2.05 million and became 2.3 million in 2019 with $0.8 \%$ of annual population growth. Economic activities in the Cianjur regency from 2004-2019 were still dominated by the agricultural sector as the most contributing sector with over 50\% of GDP in 2004 but it decreased to 30\% of GDP in 2019 [38]. North Cianjur itself is a polycentric region with two urban cores: (1) Puncak-Cipanas urban center and (2) Cianjur urban center which serves as the capital of Cianjur regency. Puncak-Cipanas urban center is developed mainly due to market mechanism, as tourism activities are increasing to meet the demand of Jakarta's inhabitants. In contrast, Cianjur urban center has been planned as a center of the settlement area and government center in Cianjur Regency. This research focused on the North Cianjur region as it is the most rapidly urbanized area in the Cianjur regency while the South Cianjur region is still predominantly rural. North Cianjur is also passed by one of the busiest road networks, namely Puncak artery road, which connects Jakarta Metropolitan Area and Bandung Metropolitan Area [2]. In this research, we focus on observing and analyzing the urban expansion, regional typology, and the changes of urban form in the North Cianjur region. 


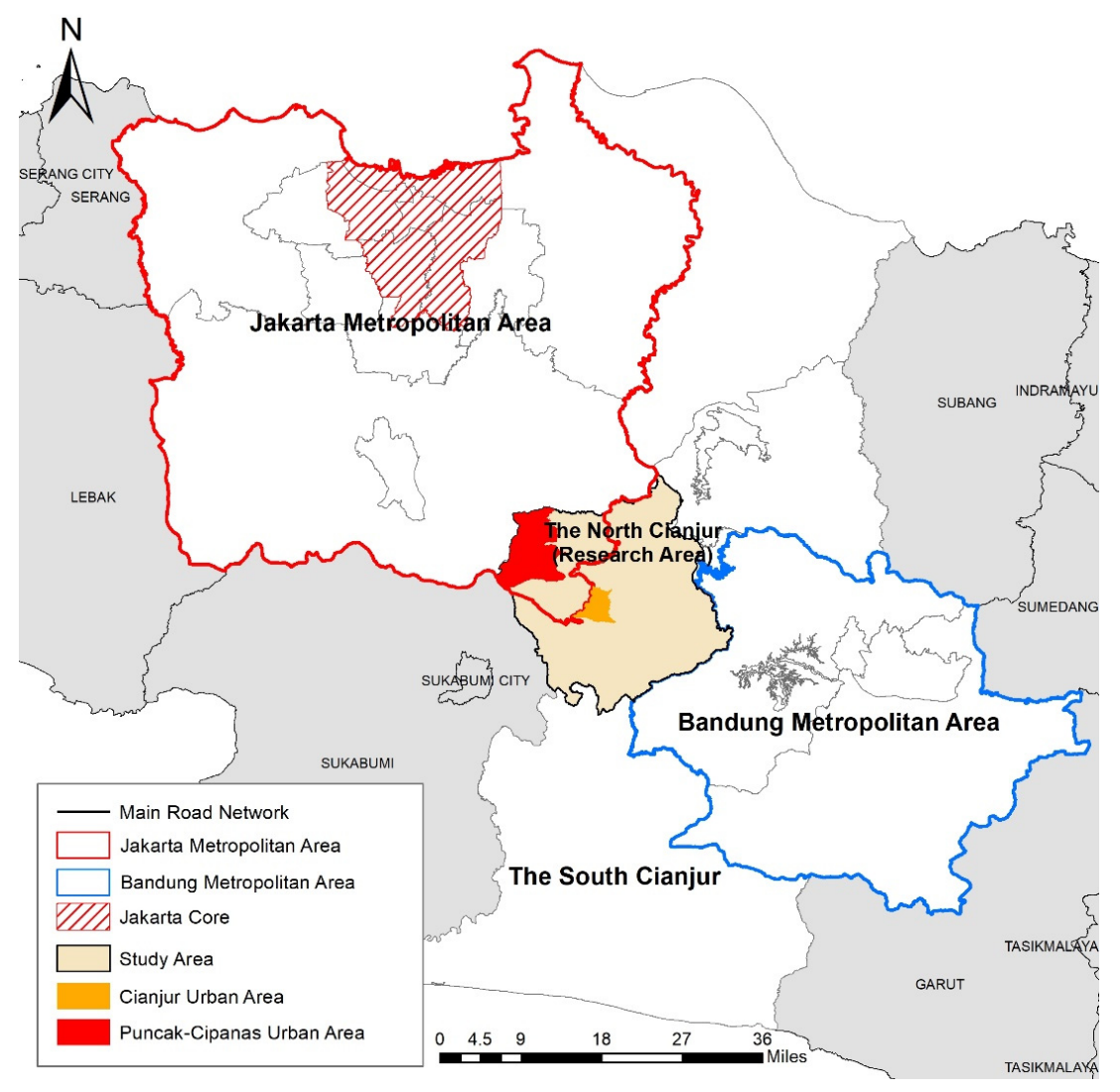

Figure 1. Research Area Map.

\subsection{Data}

The data used in this research are remotely sensed land-use data from LANDSAT satellite imagery in 2004-2019. The classification process in this study was supervised classification with a maximum likelihood algorithm, where we used training areas/training set derived from field observation. We classified land-uses into six categories: built-up (consisting of settlements, urban facilities, industrial areas, trade, and services areas), dryland (barren land and open land), mix garden (bushes and plantation), forest, paddy fields, and water (rivers and lakes). Additional data used in this research were statistical data of the Cianjur regency including socio-economic condition, main transportation network of West Java Province, and spatial planning data of Jakarta Metropolitan Area, Bandung Metropolitan Area, West Java Province, and Cianjur regency.

\subsection{Methods}

\subsubsection{Spatial Clustering}

Spatial characterization using a regional typology approach has been used in planning as one of the zoning practices. It is specifically used to increase the efficiency of regional management or planning policy to a more specific degree $[39,40]$. Especially in the mega-urban region, managing a specific region is quite a challenge to accomplish. A more quantified and measured spatial characterization needs to be considered in the planning process to support decision making in spatial planning. In this study, the spatial clustering method offers a measurable homogeneity level of spatial characterization that has the considered spatial contiguity factor in its algorithm.

Several studies have shown how the quantitative approach is able to characterize regions amid mega-urban regions/metropolises. Housley [41] used spatial clustering to identify mega-urban region groups based on socio-economic variables and also managed to explain the possible network in the regions within the same cluster, resulting in a blueprint for future work in this area. Fang and 
$\mathrm{Yu}$ [42] used clustering to examine the spatial expansion of urban agglomeration over time-series data, which then also defines the degrees of urban agglomeration and depicting strategy for sustainable urban agglomeration. The clustering method could also act as the base for infrastructure development, as suggested by Rodrigue [43] and Kin et al. [28], where the interconnectivity of the mega-urban region could be explained through clustering analysis and regions with relatively similar characteristics will behave roughly the same. In conclusion, clustering methods in a mega-urban context provide more than a regional typology or classification, but also useful for forming and focusing strategic planning policy.

One of the spatial characterization methods is making zones based on similarity/homogeneity in the region's characteristics that might consider multi-dimensional data to cover its physical and socioeconomic variables. This research uses a quantitative approach in defining typology to achieve more homogenous zones. Regional typology was performed using spatial clustering analysis to group data objects based on information found in the data that describe the objects, similarity in their characteristics, and their spatial closeness [44].

In this study, the analysis unit is villages with physical and socio-economic variables, including spatial proximity between villages. Then the clusters of villages were defined by using Rustiadi's Quantitative Zoning Method developed by Rustiadi and Kobayashi [13]. In performing spatial clustering analysis, there were several steps consisting of data preparation, data standardization to overcome the different measurement unit of variables, testing some alternatives of spatial contiguity weight, and calculating the closeness between each spatial unit based on Euclidean distance method. Cluster formation in this research was assumed following three zone categories as usually found in metropolitan/mega-urban areas consisting of: (i) urban cluster; (ii) peri-urban cluster; and (iii) rural cluster $[45,46]$.

Data standardization was carried out using the formula in Equation (1):

$$
z=\frac{x-\mu}{\sigma}
$$

where

$z=$ standardized value

$x=$ variable's original value

$\mu=$ mean

$\sigma=$ standard deviation

Then, contiguous spatial clustering method formula is explained in Equation (2) [10]:

$$
D_{i j}=\sqrt{\left(z_{1 i}{ }^{\prime}-z_{1 j^{\prime}}\right)^{2}+\left(z_{2 i}{ }^{\prime}-z_{2 j^{\prime}}\right)^{2}+\ldots+\left(z_{m i}^{\prime}-z_{m j}^{\prime}\right)^{2}+\beta\left\{\left(X_{i}^{\prime}-X_{j}^{\prime}\right)^{2}+\left(Y_{i}^{\prime}-Y_{j}^{\prime}\right)^{2}\right\}}
$$

where

$D_{i j}$ is Euclidean distance value between object $i$ and $j ; z$ is the standardized value of variables for object $i$ and $j ; m$ is the number of variables used in the research; $X$ and $Y$ is a centroid coordinate of each spatial unit analyzed; and $\beta$ is spatial contiguity weight.

The effect of spatial contiguity factor in cluster formation will be stronger when the $\beta$ value is more than $1(\beta>1)$ and will be smaller when $\beta$ value is getting closer to 0 . This research used exploratory approach in deciding on the $\beta$ value that should be tested, which ranges from $\beta=0.5 ; \beta=1 ; \beta=2$; and $\beta=4$. The results were then compared using a $C V$ (Coefficient of Variation) where the lowest value of $C V$-showing less variety between cluster members, thus representing a better clustering. $C V$ was calculated based on standard deviation $(\sigma)$ and mean $(\mu)$ value of Euclidean distance between members of the cluster, the formula for $C V$ can be seen in Equation (3) as follows:

$$
C V(\%)=\frac{\sigma}{\mu}
$$




\subsubsection{Spatial Metric}

The spatial metric is a method to quantify spatial patterns of land use based on several metrics or indices using raster-based data on a defined landscape [47,48]. Spatial metrics, often called landscape metrics, have been proposed as a method to measure landscape pattern changes and forms [49-51]. In regional studies, spatial metrics are typically used to quantify urban form in a certain region [49]. Urban form is not only a visual aspect of a region; it also affects and is affected by various other factors in a region's development $[52,53]$. Studies regarding metropolitan and mega-urban areas using the spatial metric as a methodological approach often come in the form of sprawl assessment $[23,32,51]$. Studies in suburban or even rural areas are also found using spatial metrics, where rural fragmentation is an apparent issue in suburban areas [5].

By examining urban form, some development policies could also be specified into detail. In order to develop a sustainable region, several aspects should be achieved, such as: (i) high compactness, (ii) high contiguity, (iii) high connectivity, and (iv) high diversity (Figure 2) [54,55]. These indicators are well-suited to be implemented in regional studies, especially suburban regions with high dynamics and irregular land use changes. High compactness means that urban extent of a region will be kept in a manageable size and density [56]; high contiguity means that urban areas are contiguous (physically connected) and there are clear boundaries between urban and non-urban areas [57]; high connectivity means that urban areas are not fragmented or separated without any infrastructures or any other instruments to support connectivity [58]; high diversity tends to focus on mixed land-use composition, where mixed land use coupled with compactness will result in reduced transportation costs [59].

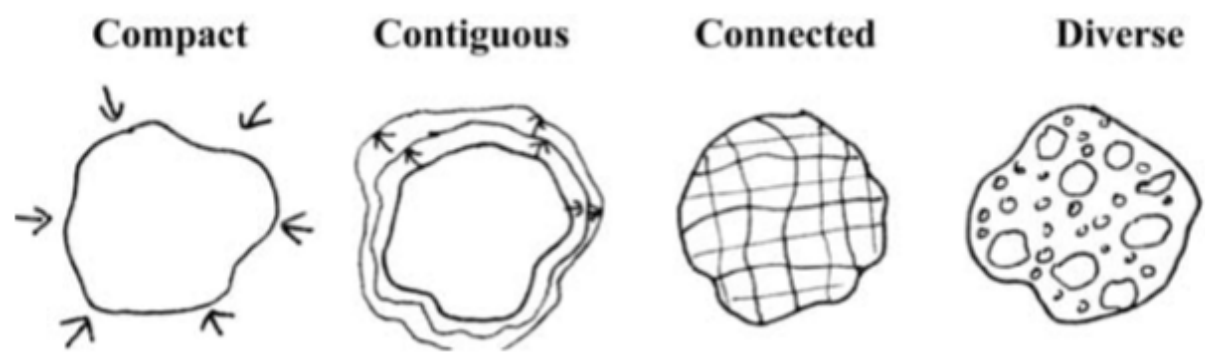

Figure 2. Sustainable Urban Form Indicator [55].

Landscape in this research refers to the urban form of each zone resulting from the spatial clustering method. In this research, seven metrics were used to measure the pattern of land-use change caused by urban expansion in the North Cianjur. These 7 metrics represent several aspects of sustainable urban form, where Patch Density (PD), Percentage of Landscape (PLAND), and Shape Index (SHAPE) represent compactness, Contiguity Index (CONTIG) represents the contiguous aspect, Cohesion (COHESION), Mesh (MESH), and Split (SPLIT) represent the connectivity aspect. The explanation about those metrics can be read in Table 1 . Those 7 metrics were then divided into 4 indicators where each indicator could be explained with 1 or more metrics (see Table 1): (i) Density indicator shows landscape dominance and density of a land-use class; (ii) Continuity shows physical connectedness of a land-use class as well as its contiguity; (iii) Clustering shows the level of fragmentation and clusters formed in a land-use class; and (iv) Shape shows the level of irregularity in a land-use class where more irregularity means that the shape is less compact and more complex. These indicators are used to explain urban form dynamics in North Cianjur due to the urban expansion process. Spatial quantitative calculation on these metrics was done using FRAGSTATS software [47], with analysis levels on a class level (see Figure 3). It consists of groups of patches (collection of nearby cells with similar values). This level lies in the second level used to describe landscape pattern at the top level. In this research we used land-use type as a class level. In order to measure the metrics in the land use-class level, the pattern of patches which lies in level 3 was used as a base for calculating the pattern of each land use class. 
Table 1. Spatial Metric Analysis [47].

\begin{tabular}{|c|c|c|c|}
\hline Indicator & Metric & Formula & Description \\
\hline Density & $\begin{array}{l}-\quad \text { PLAND (Percentage of Landscape) } \\
\text { - } \quad \text { PD (Patch Density) }\end{array}$ & $\begin{array}{l}\text { PLAND }=\frac{\sum_{j=1}^{n} a_{i j}}{A}(100) \\
P D=\frac{n_{i}}{A}(10,000)\end{array}$ & $\begin{array}{l}\text { - The proportion of the area of certain land-use class }(i) \text { to the entire landscape } \\
\text { area, describing the landscape composition, where } a_{i j} \text { is the area }\left(\mathrm{km}^{2}\right) \text { of patch } \\
j \text { of class } i, A \text { is the entire landscape area }\left(\mathrm{km}^{2}\right) \text { of buffer belts, and } n \text { is the } \\
\text { number of patches of class } i \text {; the unit is percent, } 0<P L A N D \leq 100 \text {. } \\
\text { The number of patches of class } i \text { divided by the entire landscape area, } \\
\text { describing landscape density, where } n_{\mathrm{i}} \text { is the number of patches of class } i \text {, and } \\
A \text { is the same as above; the unit is number per square kilometer, } P D>0 \text {. }\end{array}$ \\
\hline Continuity & $\begin{array}{ll}- & \text { COHESION } \\
- & \text { CONTIG (Contiguity Index) }\end{array}$ & $\begin{array}{c}\text { COHESION }=\left[1-\frac{\sum_{j=1}^{n} p_{i j}}{\sum_{j=1}^{n} p_{i j} \sqrt{a_{i j}}}\right] \\
\left.\qquad 1-\frac{1}{\sqrt{A}}\right]^{-1}(100) \\
\text { CONTIG }=\frac{\left[\frac{\sum_{r=1}^{n} c_{i j i}}{a_{i j}}\right]-1}{v-1}(100)\end{array}$ & $\begin{array}{l}\text { - Measures the physical connectedness of patches, where } p_{i j} \text { is the perimeter of } \\
\text { patch } i j ; a_{i j} \text { is the area of patch } i j ; n \text { is the total number of patches in the } \\
\text { landscape; and } A \text { is the entire landscape area; the unit is percent, } 0< \\
\text { COHESION } \leq 100 \text {. Patch cohesion increases as the patch type becomes more } \\
\text { clumped or aggregated in its distribution and, hence, more } \\
\text { physically connected. } \\
\text { Measure spatial connectedness, or contiguity of cells within a grid-cell patch in } \\
\text { a } 3 X 3 \text { pixel template. Where } c_{i j i} \text { is the neighborhood value of pixel } r \text { in patch } i j \text {, } \\
v \text { is the sum of the values in a } 3 \text {-by-3 cell template, and } a_{i j} \text { is area of patch } i j \text { in } \\
\text { terms of number of cells. Large contiguous patches will result in larger } \\
\text { contiguity index values. }\end{array}$ \\
\hline Clustering & $\begin{array}{ll}\text { - } & \text { MESH } \\
\text { - } & \text { SPLIT }\end{array}$ & $\begin{array}{l}\frac{\sum_{j=1}^{n} a_{i j}{ }^{2}}{A}(100) \\
\frac{A^{2}}{\sum_{j=1}^{n} a_{i j^{2}}}\end{array}$ & $\begin{array}{l}\text { - The area squared of all patches in class } i \text { divided by the entire landscape area } \\
\left(\mathrm{km}^{2}\right) \text {, describing landscape fragmentation, where } a_{i j}, A \text {, and } n \text { are the same as } \\
\text { above; the unit is hectare, ratio of cell size to landscape area } \leq M E S H \leq \text { the } \\
\text { entire landscape area }(A) \text {. Lower } M E S H \text { values indicate higher fragmentation. } \\
\text { The area squared of the entire landscape divided by the area squared of all } \\
\text { patches in type } i \text {, describing landscape fragmentation, which is equivalent to } \\
\text { A/MESH and can be understood as the number of effective mesh, where } a_{i j}, A \text {, } \\
\text { and } n \text { are the same as above; it is dimensionless, } 1 \leq S P L I T \leq \text { the number } \\
\text { squared of grids in the entire landscape. Higher SPLIT values indicate } \\
\text { higher fragmentation. }\end{array}$ \\
\hline Shape & - SHAPE (Shape Index) & SHAPE $=\frac{P_{i j}}{\min P_{i j}}$ & $\begin{array}{l}\text { - SHAPE equals patch perimeter (given in number of cell surfaces) divided by } \\
\text { the minimum perimeter (given in number of cell surfaces) possible for a } \\
\text { maximally compact patch (in a square raster format) of the corresponding } \\
\text { patch area, where } p_{i j} \text { is perimeter of patch } i j . S H A P E \geq 1 \text {, without limit. } \\
\text { SHAPE }=1 \text { when the patch is maximally compact (i.e., square or almost } \\
\text { square) and increases without limit as patch shape becomes more irregular. } \\
\text { SHAPE index describes irregularity of shape/form of a class. }\end{array}$ \\
\hline
\end{tabular}




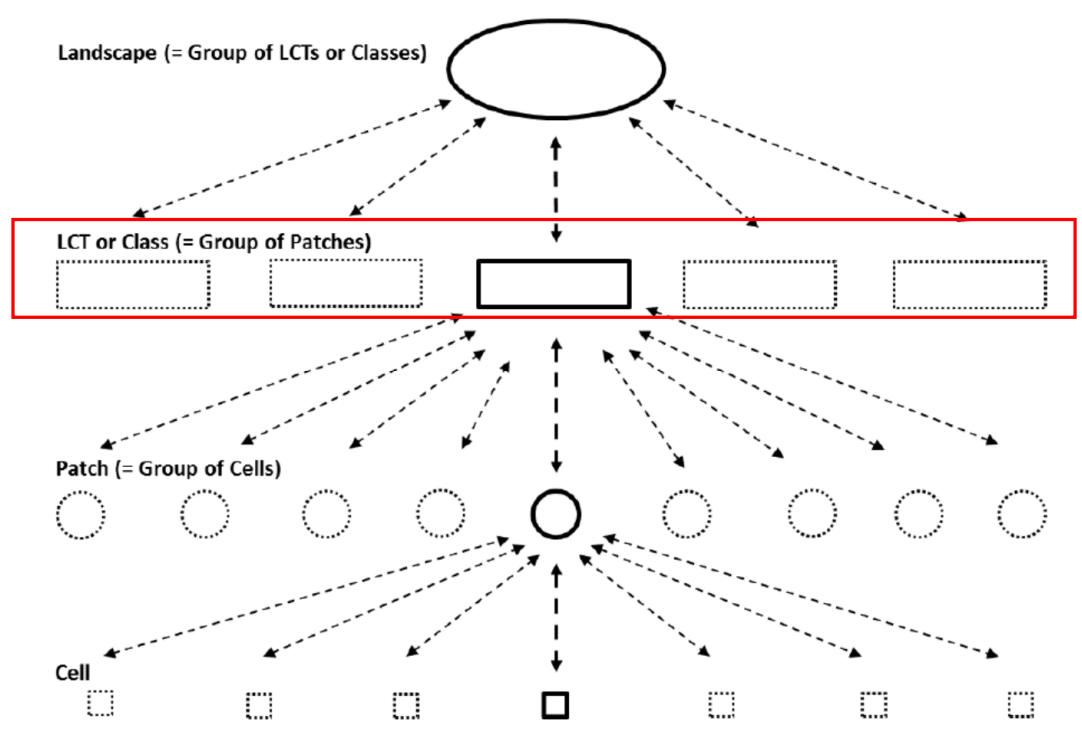

Figure 3. Class (Group of Patches) as Analysis Unit of Spatial Metric [23].

\section{Results}

\subsection{Land Use Changes in North Cianjur}

Over a 15 years' period (2004-2019) North Cianjur experienced significant change in its physical forms and land uses, primarily in its urban areas with over 100\% increase over the 2004-2019 period (Table 2). In 2004, Puncak-Cipanas urban center began to develop as a newly emerging urban area due to lack of spatial planning control and monitoring. Then in 2019, Puncak-Cipanas urban center had been developed exceeding Cianjur urban center regarding its total built-up and land-use areas (Figure 4). Land-use changes in North Cianjur were dominated by the conversion of non-urban land uses (forest, mix garden, and paddy fields) to urban land uses (built-up). This pattern confirmed the early hypothesis [1,2] that the changes were enhanced by Cianjur regency planning policy in 2011 that supports the development of Puncak-Cipanas into an urban center without detailed restriction in the zoning plan.

Table 2. North Cianjur Land-Use Composition.

\begin{tabular}{ccccc}
\hline \multirow{2}{*}{ Land-Use Class } & \multicolumn{4}{c}{ Total Area (Ha) } \\
\cline { 2 - 5 } & $\mathbf{2 0 0 4}$ & $\mathbf{2 0 0 9}$ & $\mathbf{2 0 1 4}$ & $\mathbf{2 0 1 9}$ \\
\hline Built-up & 6109.21 & 7274.66 & 9775.89 & $14,114.1$ \\
Paddy & $40,803.08$ & $40,171.09$ & $38,684.08$ & $35,309.25$ \\
Mixgarden & $46,559.59$ & $46,272.78$ & $45,617.08$ & $45,594.8$ \\
Dryland & 6759.59 & 6672.78 & 6533.24 & 6150.15 \\
Forest & 6095.79 & 5935.95 & 5716.97 & 5158.96 \\
Water & 1886.49 & 1886.49 & 1886.49 & 1886.49 \\
\hline Total & $108,213.8$ & $108,213.8$ & $108,213.8$ & $108,213.8$ \\
\hline
\end{tabular}

\subsection{Regional Typology of North Cianjur}

Regional typology in this research was assumed to be cluster-based, meaning that the grouping of geographical analysis unit was based on the proximity, similarity, and intensity of relationships between units. The regional typology approach in regional planning is often implemented in the zoning scenario to facilitate and improve the efficiency of management of a region as well as to implement certain policies and development direction [39]. The regional typology in this research was defined by the result of spatial clustering, whereas each value of variables was grouped based on high, mid and low values showing the characteristic of urban, peri-urban, and rural, as can be seen in Table 3. 

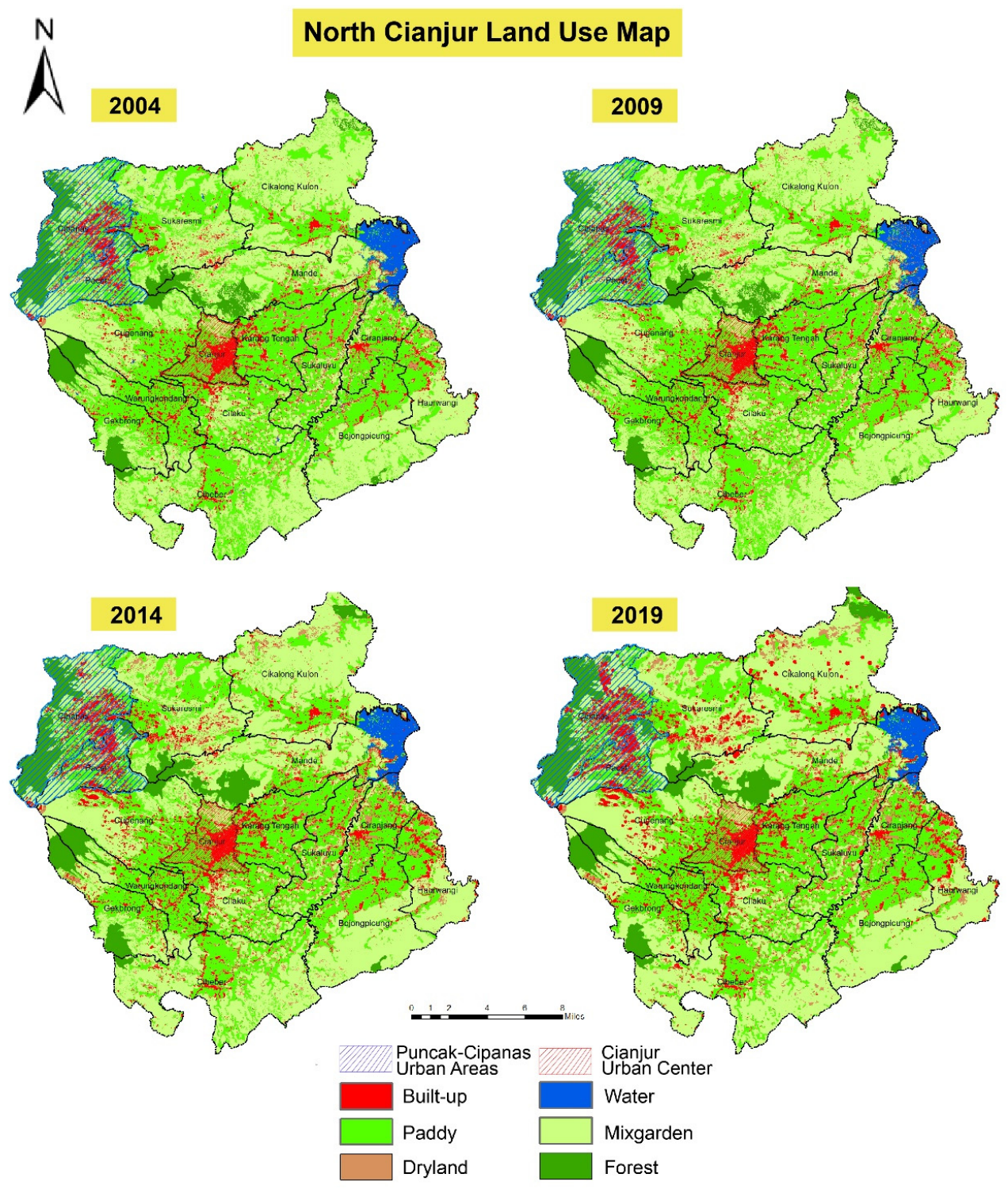

Figure 4. Land-Use Maps of North Cianjur from 2004-2019.

Table 3. Regional Typology Characteristics.

\begin{tabular}{ccccc}
\hline Variables & Definition & Urban & Peri-Urban & Rural \\
\hline z1 & Population Density (person/ha) & High & Mid & Low \\
z2 & Village Facilities Index & High & Low & Mid \\
z3 & Built-Up Area (ha) & High & Mid & Low \\
z4 & Agriculture Area (ha) & Low & High & Mid \\
z5 & Farmer Household Percentage (\%) & Low & Mid & High \\
z6 & Non-Farmer Household Percentage (\%) & High & Mid & Low \\
z7 & Distance to the Main Transportation Network (km) & Low & Mid & High \\
z8 & Total Public Facilities (unit) & High & Mid & Low \\
z9 & Numbers of Households Below Poverty Line & High & Mid & Low \\
& (Household) & & & Low \\
z10 & Numbers of Households Above Poverty Line & High & Mid & \\
\end{tabular}

Based on several alternatives of spatial contiguity weight $(\beta)$ (i.e., $\beta=0.5 ; \beta=1 ; \beta=2 ; \beta=4$ ), the optimal result of the contiguous spatial clustering analysis was obtained at $\beta$ value of 0.5 which 
is the lowest average of $C V$ value compared to other $\beta$ values (Figure 5). Spatial distribution of regional typology in North Cianjur was dominated by peri-urban typology spreading in the middle to southern part of the research area. Rural areas were mostly located in the northern part of the research area. Meanwhile, urban typologies matched with the spatial planning policy of two urban areas, Cianjur urban center and Puncak-Cipanas urban center (Figure 5).

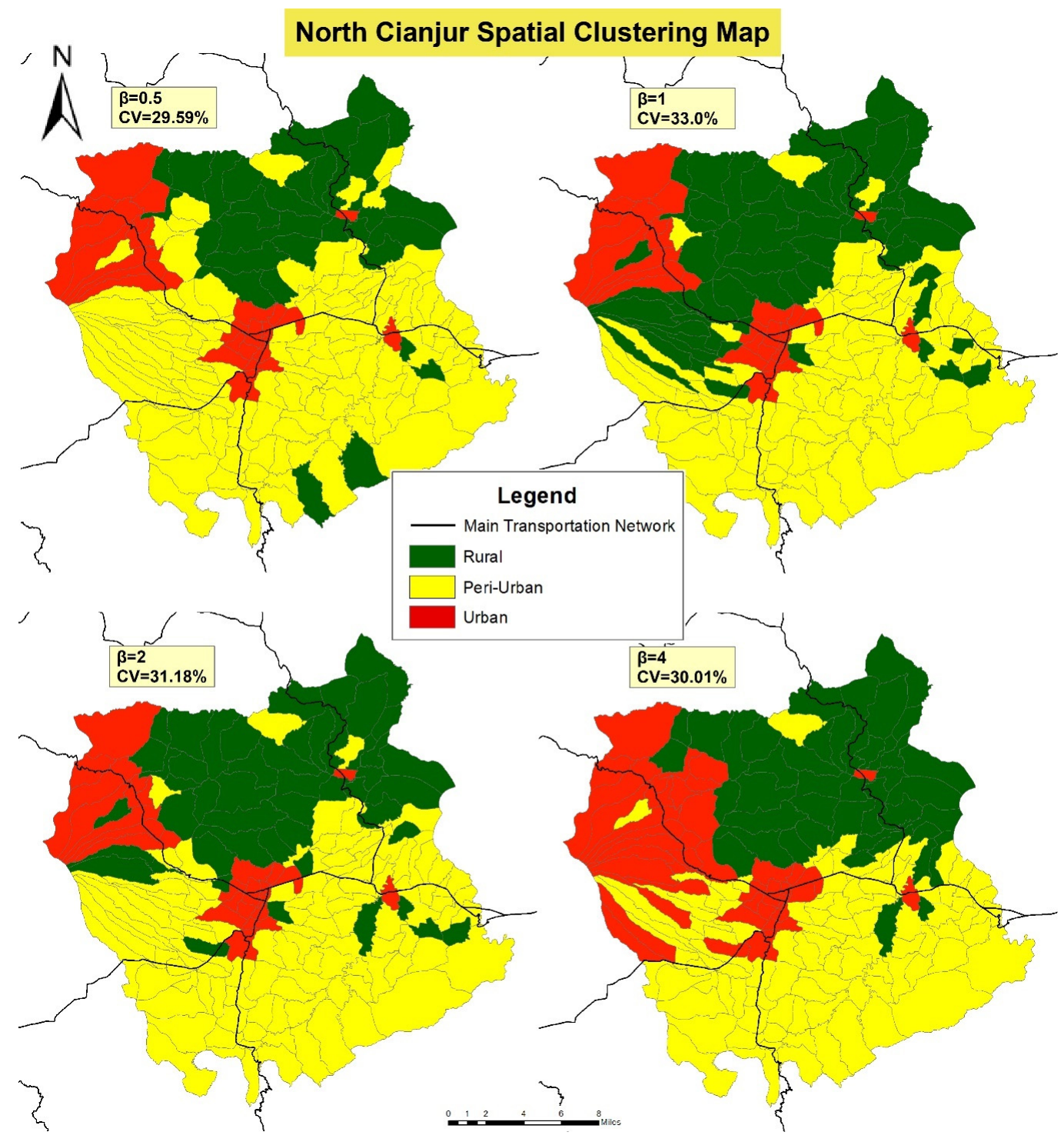

Figure 5. Spatial Clustering Result.

The result of spatial clustering in this analysis is quite sensitive to the value of $\beta$ (Figure 5). In this analysis, $\beta$ functions as the weight of spatial contiguity represented as a neighborhood concept based on Tobler's Law, where the adjacent objects have a closer/better relation. From the result shown in Figure 4 , it can be seen that as the $\beta$ value increases, the spatial contiguity factors will reduce the role of other factors in determining the cluster, thus the results seems unrealistic [13]. In this case geographical factors become very dominant thus we lose the characteristics of other factors in the resulting clusters [13].

Based on the optimal spatial clustering result derived from the lowest average $C V$ value $(\beta=0.5)$, the clusters were then generalized to form a smoother zoning map of regional typology (Figure 6). The generalization was done by using a majority typology of the neighboring areas to adjust the typology of a unit which is different from its surroundings. 


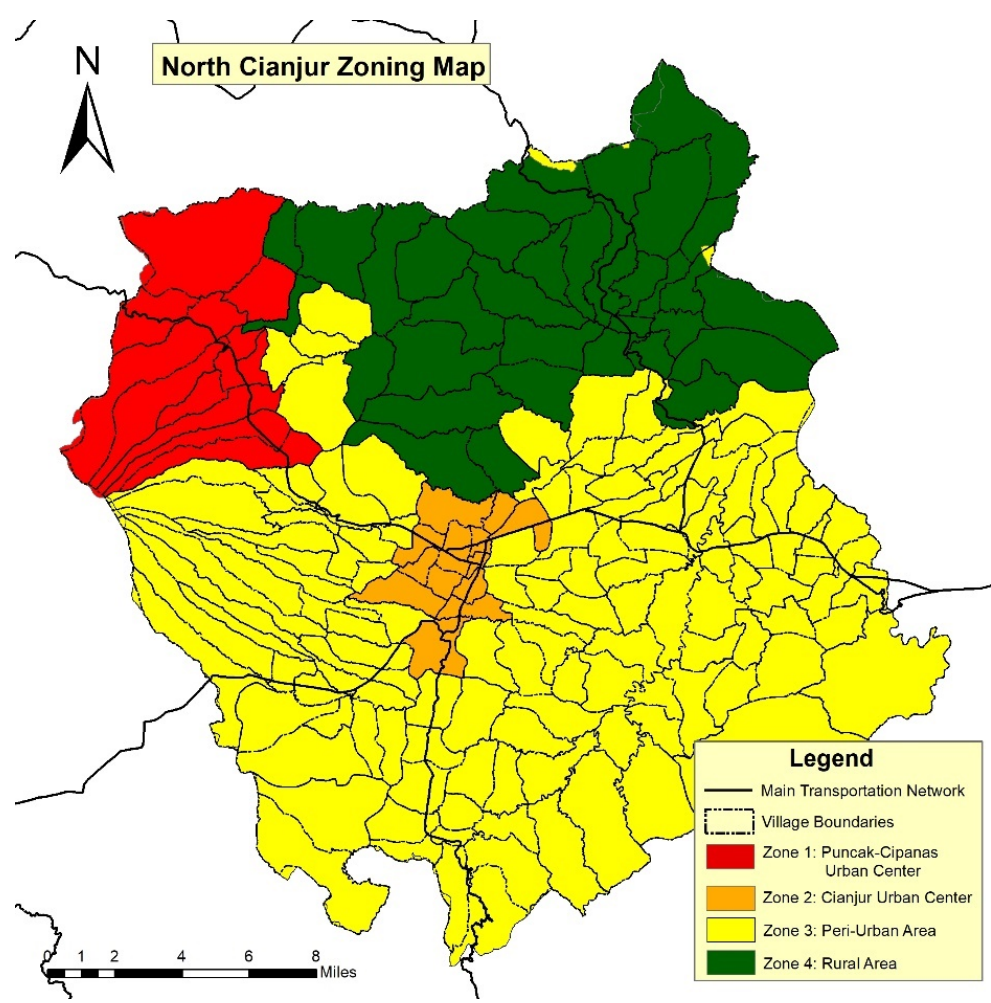

Figure 6. Zoning map of North Cianjur region.

\subsection{Spatial Pattern Dynamics of Land Use and Urban Form in North Cianjur}

Based on its trend, spatial pattern of built-up area in North Cianjur had experienced increasing density, continuity, and irregularity, while decreasing fragmentation. Density indicators as shown by PD and PLAND have increasing values. PD represents the density of built-up areas across the observed landscape where the increasing value shows that spatial distribution of built-up land is more concentrated and compacted. Furthermore, PLAND metrics show an increase in the total area of built-up land-use. Regarding the continuity indicator, the COHESION metric has increased as there was an increase in total distribution and total area of built-up, thus physically this region tends to become a more intense urban corridor. Meanwhile, the CONTIG metric is experiencing a slight decrease due to the more widespread distribution of built-up area as indicated by the increasing average distance between built-up clusters. In shape indicator, the SHAPE metric has increased to an increasingly irregular urban shape due to its organic growth (e.g., growth without planning). Meanwhile, the indicator that experienced a decrease was fragmentation, where an increase in MESH value and a decrease in SPLIT value occurred due to the growth of built-up areas which previously had a small and disperse pattern that is becoming more massive and clustered (Figure 7).

Contrarily, non-built-up areas, mainly paddy fields and mix garden, show the opposite pattern to the built-up area characteristic, considering that these land-use types have become the major types of land use which were converted into built-up areas. The trend of non-built-up area (paddy and mixed garden) have seen an increase in fragmentation (increase in SPLIT value, decrease in MESH value), and decrease in density (i.e., decrease in PD and PLAND value), continuity (i.e., decrease in COHESION value), and irregularity (i.e., increase in SHAPE value). However, forest, water, and dryland area didn't experience any significant changes because the minimum conversion occurred in these land-use classes, thus they were excluded from the analysis in Figure 7.

Urban form changes as shown in Table 4, have a slight differentiation in each of North Cianjur's zones. Urban zones (Z1-Puncak-Cipanas Urban Center and Z2-Cianjur Urban Center) were experiencing the similar form of changes as all of North Cianjur, where zone 1 (Puncak-Cipanas Urban Center) experienced significant increase in density, while zone 2 (Cianjur Urban Center) experienced 
significant increase in continuity and significant decrease in fragmentation. Zone 3 (Peri-Urban Area) has a different pattern with significant increase in fragmentation, showing the indication of sprawling where a built-up area has become more scattered throughout the landscape. Zone 4 (Rural Area) also shows the indication of sprawling indicated by significant decrease in continuity and slight increase in fragmentation.

\section{DENSITY}

Patch Density (PD)

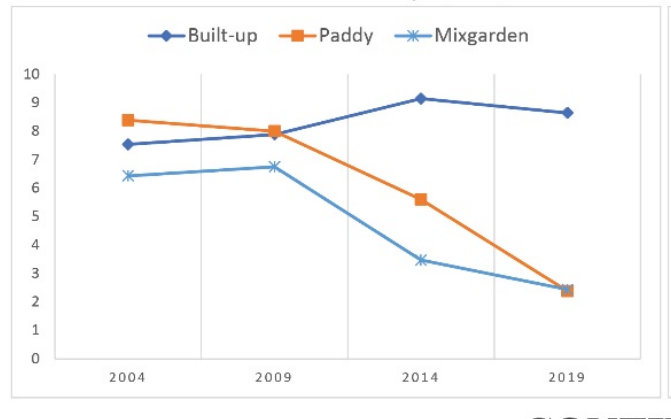

Precentage of Landscape (PLAND)

$\rightarrow$ Built-up $\rightarrow-$-Paddy $\rightarrow$ Mixgarden
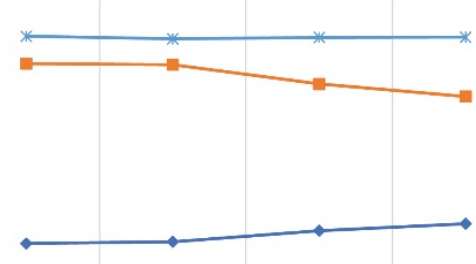

$2004-2009-2014=2019$

200

\section{CONTINUITY}

COHESION

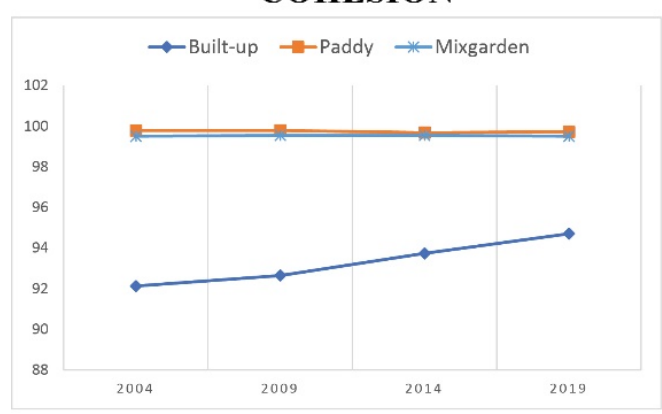

Contiguity Index (CONTIG)

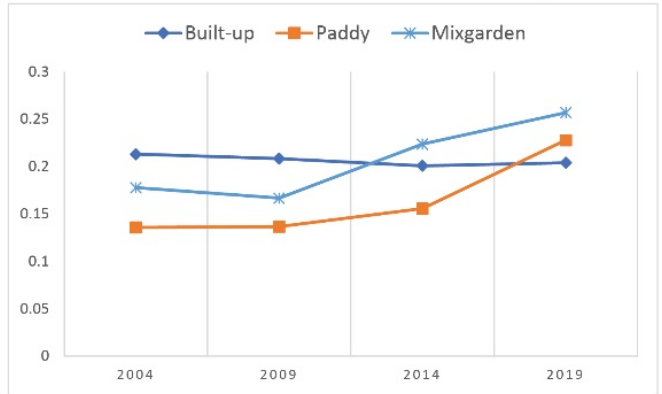

2009

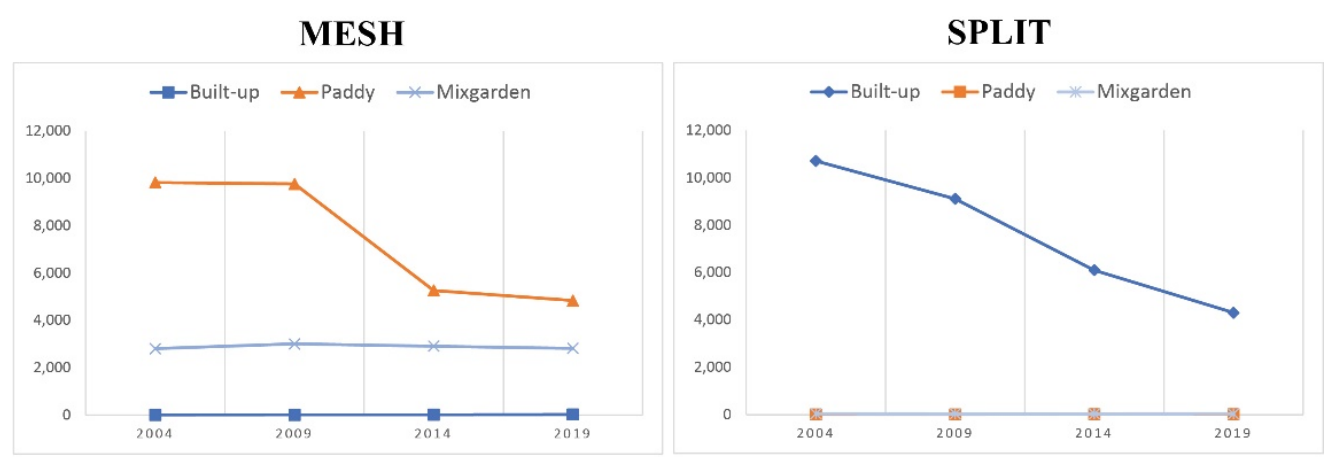

SHAPE

Shape Index

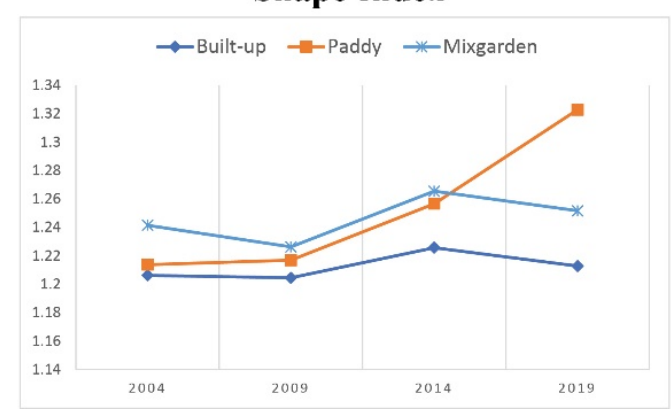

Figure 7. Graphic of Spatial Pattern and Urban Form Changes in North Cianjur. 
Table 4. The Trend of Urban Form Changes in North Cianjur.

\begin{tabular}{cccccc}
\hline \multirow{2}{*}{ Urban Form Indicators } & \multicolumn{5}{c}{ The Trend of Urban Form Changes } \\
\cline { 2 - 6 } & All & Z1 & Z2 & Z3 & Z4 \\
\hline Density & $\uparrow \uparrow$ & $\uparrow \uparrow$ & $\uparrow$ & $\uparrow \uparrow$ & $\uparrow$ \\
Continuity & $\uparrow$ & $\uparrow$ & $\uparrow \uparrow$ & $\uparrow$ & $\downarrow \downarrow$ \\
Shape & $\uparrow$ & $\uparrow$ & $\downarrow$ & $\uparrow$ & $\uparrow$ \\
Fragmentation & $\downarrow \downarrow$ & $\downarrow$ & $\downarrow \downarrow$ & $\uparrow \uparrow$ & $\uparrow$ \\
\hline
\end{tabular}

${ }^{1}$ Note: $\uparrow=$ slight increase; $\uparrow \uparrow=$ significant increase. $\downarrow=$ slight decrease; $\downarrow \downarrow=$ significant decrease. ${ }^{2}$ Note: Column "All" refers to overall landscape, where "Z1-Z4" refers to zone number in Figure 5. ${ }^{3}$ Note: Z1 = Puncak-Cipanas Urban Center; Z2 = Cianjur Urban Center; Z3 = Peri-Urban Area; Z4 = Rural Area.

In general, urban form can be classified into two main categories: compact or sprawl, with other forms being breakdown from those two main classifications [25,60]. Moreover, the concept of city development (i.e., Garden City, Compact City, Transport-Oriented Development, Low Carbon City, etc.) is mainly relied on urban form and the regulation that forming spatial configuration to achieve the objectives of the spatial planning [26,52]. According to the trend, the urban form in the North Cianjur indicates a poly-centric region with 2 centers (Puncak-Cipanas urban center and Cianjur urban center) with sprawl and dispersed patterns outside the centers (urban zones) and more compact pattern within the urban zones. The development of built areas has 2 main patterns: ribbon and leapfrog patterns. The ribbon pattern was found along the main route of the Jakarta-Bandung corridor while the leapfrog pattern occurs outside of the urban zones in the northern and southern parts of the research area. Both patterns of development occurred due to lack of spatial planning and control.

\section{Discussion}

\subsection{Urban Expansion and Lacking of Cianjur Regency Spatial Planning Policy in Managing Urban Expansion}

Urban expansion is one of the consequences of regional development that occur through a variety of patterns caused by various driving factors. Continued expansion in certain urban centers might also lead to the formation of mega-urban regions. The driving factors of urban expansion can be categorized into three main factors. The first is the growth, intensification, and diffusion of economic activities, which require additional amounts of urban land [53,55]. The second is the growing interconnectivity of urban centers, mostly through the setting of multimodal transport corridors [56]. The third is the specialization and interdependency of urban centers and the intense passenger and freight interactions this process creates [28]. In other words, urban expansion occurs along with the demand for additional land (often in forms of urban land-uses) to facilitate economic growth. Urban expansion, as indicated in the result, has managed to changes the urban form of a region. At the same time, it also means that economic factors play a fundamental role in the demand for expansion.

North Cianjur, as part of the JBMUR (Jakarta-Bandung Mega-Urban Region) conurbation corridors, has undermined urban expansion which is strongly influenced by the presence and dynamics of the two adjacent metropolitan areas. Urban expansion in North Cianjur exhibits those of a similar characteristics within urban expansion in Monsoon Asia's mega-urban development [1,2] which comes from its two adjacent metropolitan areas. In addition, the growth of Cianjur urban center itself has driven further urban expansion. Based on the spatial growth pattern of built-up areas, there are three urban centers that trigger urban expansion in this region, consisting of:

- Expansion driven by Jakarta Metropolitan Area Expansion driven by Jakarta Metropolitan Area is the biggest driving factor of urban expansion in North Cianjur. This expansion has led to the formation of Puncak-Cipanas urban center (Z1), that previously was planned as protected and agricultural areas. After Puncak-Cipanas urban center (Z1) was formed, this expansion factor pushed urban expansion further to the east towards Cianjur urban center (Z2) in a continuous edge expansion pattern (see Figures 8 and 9) that led to the connectedness of the Puncak-Cipanas (Z1) and Cianjur urban centers (Z2). 
- Expansion driven by Bandung Metropolitan Area Bandung Metropolitan Area is one of the urban expansion factors in the North Cianjur region in the eastern part. This expansion comes in the form of industrialization in the eastern part of the North Cianjur, as assigned by the spatial planning policy of Cianjur regency and West Java Province (i.e., the province where Cianjur regency becomes part of it). This expansion was followed by the improvement of the transportation network and planned settlement areas in Sukaluyu and Ciranjang sub-districts. This expansion comes from eastern part of the North Cianjur and is headed towards Cianjur urban center (Z2), forming Cianjur-Bandung corridor. However, the drive for expansion is not as big as the expansion driven by Jakarta Metropolitan Area, but this followed the same pattern which is continuous edge expansion (see Figures 8 and 9).

- Expansion driven by Cianjur Urban Center (Z2) Along with the regional growth, Cianjur urban center has driven urban expansion with the direction of expansion towards the south. This expansion occurs as it is supported by the existing planning instruments. This expansion follows the improvement of transportation infrastructures which is aimed at increasing connectivity as well as decreasing the disparity between northern and southern part of the Cianjur regency. This expansion comes in the form of small and dispersed built-up areas, especially unplanned settlement areas.

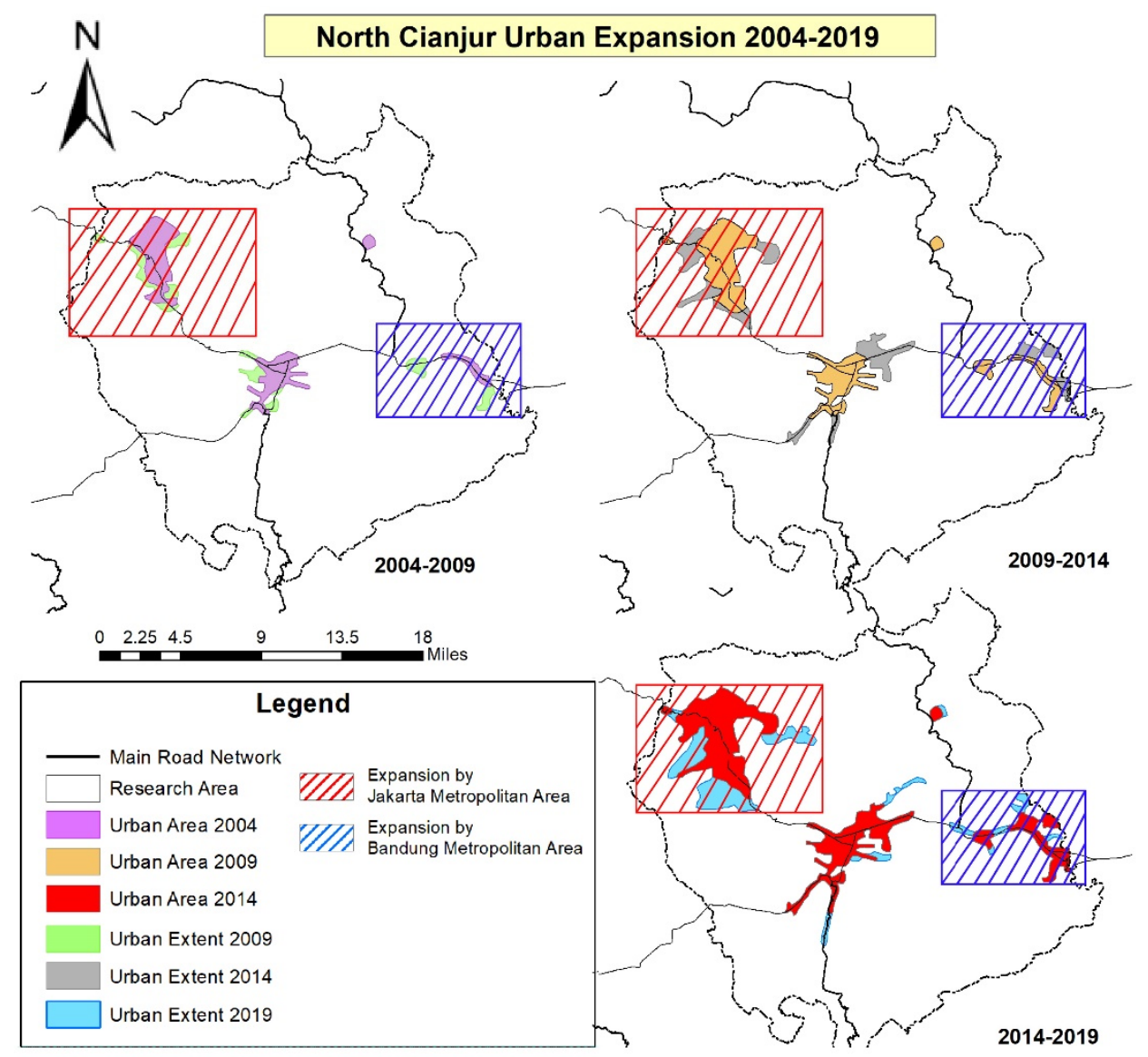

Figure 8. North Cianjur Urban Expansion in 2004-2019.

Three main factors of urban expansion over the years showed that the period of 2014-2019 saw the most significant expansion (Figure 8). The most prominent urban land uses were located in the western part of North Cianjur (Cipanas and Pacet sub-district), Cianjur urban center (Cianjur sub-district), and the eastern part of North Cianjur (Sukaluyu and Ciranjang sub-district). The main direction of urban expansion for the overall period (2004-2019) formed an urban corridor following the main transportation network that connects Jakarta-Bandung metropolitan areas. The patterns of urban 
expansion in North Cianjur are mainly dominated by the edge-expansion type in the later period (2009-2014), while in the earlier period (2004-2009) there was some expansion in the form of outlying expansion (see Figure 9). Edge expansion and outlying expansion pattern are commonly found in Monsoon Asia's mega-urban development $[1,26]$. The expansion process in North Cianjur consists of both planned and unplanned development pattern. The planned expansion pattern is the type of expansion process which was in accordance with spatial planning policies (Cianjur regency spatial planning policy and other spatial planning policies in higher hierarchy). Planned expansion can be seen in the eastern and central parts of North Cianjur, while the unplanned pattern can be seen in the western part of North Cianjur in the Puncak-Cipanas urban center.

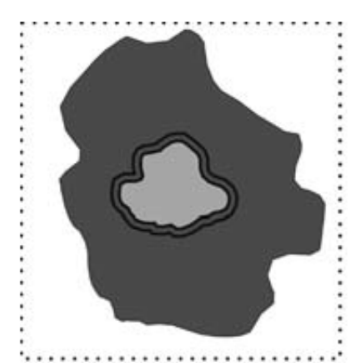

(a) Infilling

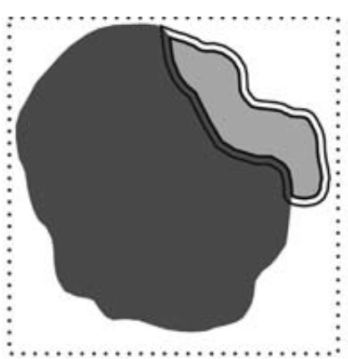

(b) Edge-expansion

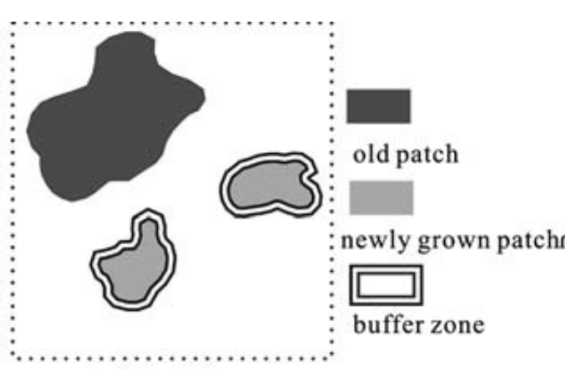

(c) Outlying

Figure 9. Patterns of Urban Expansion, derived from [26,61].

Urban form and urban expansion patterns that occur in North Cianjur show a pattern that tends to be more compact in the two main urban zones. Expansion in the urban zones continues towards the peri-urban zone, especially in areas adjacent to the urban zone and forming urban fringe structures. However, in the area outside of the urban zones, the expansion patterns were showing trends of sprawling and dispersion in the form of leapfrog features.

These trends show ineffectiveness of spatial planning policies in controlling land use changes in North Cianjur. Landscape characteristics in the North Cianjur region show the phenomenon of chaotic land use. The presence of mixed use between urban and rural land uses has led to difficulties in providing infrastructures and developing efficient agricultural activities [8,9].

The spatial planning policy of Cianjur regency is likely unable to control the urban expansion process. The Cianjur Regency Spatial Plan 2005-2015 mentioned that the Puncak-Cipanas area was not planned as an urban area, while in the revised Spatial Plan of Cianjur regency 2011-2031, Puncak-Cipanas was assigned as one of the urban centers at the local/regency level. Cianjur regency's Spatial Plan has undergone a revision, adjusting to the enactment of the Jakarta Metropolitan Area Spatial Plan 2008-2028. Recently, the new Jakarta Metropolitan Area Spatial Plan 2020-2040 has been enacted as a revision of the Jakarta Metropolitan Area Spatial Plan 2008-2028.

According to the recent regulations including Jakarta Metropolitan Area Spatial Plan 2020-2040 and Cianjur regency Spatial Plan 2011-2031, there are critical problems that may ruin spatial development planning in North Cianjur. As noted, each spatial plan in Indonesia consists of a spatial structure plan that regulates hierarchical urban centers and infrastructures development, and a spatial pattern plan that regulates the utilization of spaces in a region. In the Jakarta Metropolitan Area Spatial Plan 2020-2040, the spatial structure plan assigns Puncak-Cipanas as a buffer zone to maintain the environment. However, this area is also designated as a medium density of residential areas regarding the spatial pattern plan. In contrast, in Cianjur Regency Spatial Plan 2011-2031, the spatial structure plan assigns Puncak-Cipanas as a local urban center that supports tourism as the main economic activity in this area. However, regarding the spatial pattern plan, this area is still designated for agricultural areas with small allocation for urban land.

The asynchronous planning policies, both in between and within the regulations, has caused the inability of policies to control land-use changes in North Cianjur. These planning policies have systemic weakness where quantitative spatial characterization have not been thoroughly considered, instead, 
the characterization of each zone is mainly based on administrative boundaries and consensus between stakeholders. If planning policies are not able to accommodate the changes, a variety of problems will arise relating to the agricultural sector, changes in economic structure, acculturation and changes in social systems, as well as regional sustainability [32,62-64].

Based on the various patterns of Mega-Urban region management [33-35,55], especially in its suburban area, there are a number of suggestions and recommendations for the improvement of the Cianjur regency spatial planning policy, especially for managing land-use changes in North Cianjur. Regional typology processes can be considered in determining regional zoning plans and spatial structure, where urban, peri-urban, and rural zones will have different policies and approaches in both spatial planning and zoning regulations. Spatial planning processes and products in Indonesia are still less concerned about urban form. The urban form approach should be applied in the formulation of spatial planning policies, especially for controlling sprawl, developing more compact areas along with proper facilities including open spaces distribution, controlling ribbon-shaped expansion, and developing open spaces with the greenbelt scenarios. This approach is important particularly in the region with higher spatial-temporal land-use dynamics.

Some recommendations on planning policy could be formulated based on its spatial characteristics and urban form trends. The Puncak-Cipanas urban center (Z1) planning recommendation is to control the growth of urban areas into a more linear structure and continuous urban corridor, due to agricultural and forest areas surrounding its growing urban area. The Cianjur urban center (Z2) planning recommendation is to become an urban center that is more compact and connected with the concentration of expansion intensity in this zone. The compact direction in this zone also needs to be supported by improving the quality of infrastructure and transportation networks to improve connectivity between regions and minimize transportation costs. The peri-urban area (Z3) planning recommendation is to center and limit the urban expansion that occurs in this zone towards the Cipanas-Cianjur urban corridor, so that the overall urban form in overall North Cianjur is more contiguous, connected, and diverse. Green belt schemes could also be implemented in this zone as an instrument to limit urban growth. The rural area (Z4) planning recommendation is to implement zoning regulation on its forest and agricultural area so that land-use conversion into urban area could be controlled.

\subsection{Insight and Addition from Quantitative Zoning Approach in Urban Expansion Management in the Suburban Areas of a Mega-Urban Region}

The debate between the qualitative and quantitative planning approach did not imply which planning approach is better. Instead, it is meant to be complementary and should be done in tandem. Qualitative planning might have an advantage in which qualitative planning provides domain-specific characteristics that human experts might use to differentiate between plans, thus being able to produce results of greater practical value. However, on a more macro scale and with a more varied variable, the quantitative approach has its edges in the practicality and replicability $[65,66]$.

This study uses a combination of spatial metric and spatial clustering method in an effort to perform more objective, measured, and accurate spatial characterization of a suburban area in a mega-urban region, as well as monitoring its urban form. While the exact methodological approach differs from one study to another, several studies have shown its similarities in terms of spatial clustering and urban form aspects, and how it helps towards understanding the mega-urban development process. One of the examples is that of how spatial clustering approach was used to promote more coherent regional coordination and collaboration. in terms of economic, infrastructure, and land-use development in numerous cities or metropolitans $[41,67]$. Some studies $[41,42,68,69]$ suggest that spatial characterization in a mega-region are indeed essential to redefine the interactions inside a mega-urban region and that it is not a mere consequence of uncontrolled expansion. Form characterization will promote a more optimal infrastructure provision [70], land allocation [27], and overall a more coordinated urban form of a region, which then will be a step closer in achieving sustainable urban form [54]. 
Quantitative measurement over urban form and its transformation due to the expansion process can be used as one of the bases for regional development, especially in major cities $[8,10,32]$.

This research then tries to implement a combination of both spatial clustering and urban form measurement to reach a better understanding of the dynamics of suburban areas in mega-urban regions. Using a spatial clustering method, several zones were formed based on their physical and socio-economic variables. Two urban zones, namely Puncak-Cipanas urban center (Z1) and Cianjur urban center (Z2) were characterized using a spatial clustering method. Puncak-Cipanas urban center (Z1) was formed as the result of expansion from Jakarta Metropolitan Area, where this zone is a highland mountainous area where land-use changes were dominated by developing villas, hotels, resorts, restaurants, and other tourism infrastructures. The other urban zone, Cianjur urban center (Z2), was a relatively flatter area which has been planned as an urban center and the government center of the Cianjur Regency. Urban form trends and characteristics across these two urban centers show that Puncak-Cipanas urban center (Z1) tends to expand with higher density and more irregularity, while Cianjur urban center (Z2) tends to be more compact. The different characteristics resulting from spatial clustering and urban form analysis give more detailed information about the urban areas and deeper insights on how the regions with such characteristics should be planned. The quantitative results from both methods complement each other, making it possible to produce a more detailed planning policy.

The quantitative zoning approach in this study could help to enhance and improve planning policy in suburban areas. Unlike planning in a core city, which mainly focuses on urban activities, planning in the suburban region must divide its focus across several key aspects, including environments, rural area prosperity, and how the suburban area will be able to support the mega-urban region cores [71,72]. Implementation of the quantitative zoning approach was in line with how insufficient the Indonesian planning system is in managing the suburban areas of mega-urban regions, where this situation is common in megacities in Asia or developing countries.

The planning system in Indonesia leaves no region unplanned, although the directive given in several regions is less detailed when those regions did not serve a strategic function. The planning system in Indonesia employs a hierarchical planning system, where planning begins on a national scale, followed by a detailed plan in a provincial and municipality/city level, then the more detailed planning only in strategic or planned urban areas. The problems of Indonesia's planning system begin here, where a region outside of the strategic and planned urban regions did not get a detailed plan even though those regions have a high rate of growth or urbanization as they are located in the suburb, causing a disruption of the spatial plan.

Based on the analytical result displayed in this research, the quantitative zoning approach has contributes to the understanding of the urban expansion process as well as the regional characteristics themselves. The clear extent of expansion forces and how they spatially affect urban form configuration in this region are also properly exhibited. Several recommendations on planning and development policy could then be formulated based on the spatial progression of urban expansion, as well as how to mitigate or control the pattern of urban expansion. To some extent, the methodological approach in this research that combines spatial clustering and spatial metric to characterize spatial pattern in a region quantitatively could be replicated in addressing the similar issue of suburban development in other mega-urban regions, especially in Asia or developing countries that have weak spatial planning policies.

\section{Conclusions}

Urban expansion in North Cianjur has transformed this region into a polycentric region, with the emergence of Puncak-Cipanas urban center (Z1) as the new urban zone with mixed land-use characteristics affected by the Jakarta Metropolitan Area urban expansion, and Cianjur urban center (Z2), the main urban center and the capital of the Cianjur regency. Other typologies are peri-urban area $(\mathrm{Z} 3)$ and rural area $(\mathrm{Z} 4)$. The peri-urban area $(\mathrm{Z} 3)$ is an intermediate zone with mixed urban-rural 
characteristics and has a high land use conversion rate, where rural area (Z4) is the zone with the least urban development and is least affected by urban expansion. Spatial trends in land use patterns and urban form dynamics indicate that urban zones have developed to be more compact and denser with ribbon patterns. Meanwhile, in the area outside of the urban zones, more specifically outside main road networks, the urban form shows sprawl and dispersed characteritics with a leapfrog development pattern so that the dynamics occurring in the North Cianjur increasingly show a tendency towards the formation of chaotic land-use.

As the observed and analyzed trends, urban expansion in the North Cianjur has become one of the main challenges in the regional planning. In the current condition, the trend of expansion has not been accommodated very well by the planning policy so it leads to the impact which are mostly negative such as chaotic land-use, urban sprawl, etc., resulting in non-sustainable regional development. Low integration and synchronization between planning policies has also become one of the factors that exacerbate the situation. The inability of spatial planning policy to manage various factors that influence region's dynamic might also be the main cause of the regional disparity between the north and southern part of Cianjur regency. The North Cianjur region needs a better spatial plan which is able to manage land-use changes in the context of JBMUR planning and dynamics, and a quantitative approach is required to develop zoning regulation with a more measured approach in dealing with the various interest of stakeholders. A more detailed plan based on urban form is also required to effectively manage land use changes in a very-dynamics region such as the North Cianjur.

The quantitative zoning methodological approach used in this research managed to give a more detailed point of view over the characteristics and dynamics of North Cianjur based on empirical spatial and socio-economic variables, as well as the spatial configuration or urban form changes in this region. Findings and insight from the quantitative zoning approach as shown in this research could give a clearer interpretation over the forces and the extent of expansion, as well as how they change the region as seen from spatial features. The nature of Monsoon Asia's mega-urban development, in which the metropolitan areas expanded into its suburb and hinterland being captured by this quantitative zoning approach along the forces of expansion behind it as shown in the result. The quantitative zoning approach has managed to give us a more objective, measured, and accurate zones to depict the dynamic and the impact of expansion over the suburb of a mega-urban region. Thus, this method could be used to describe spatial pattern and dynamics in other mega-urban regions that were based on empirical data expressed in quantitative indicators.

This research mainly explains the physical aspects of urban expansion and urban form using a quantitative zoning approach, whereas urban expansion also brings more impacts on the socio-economic aspects that have not been further explained in this research. Therefore, future possibilities in developing this research are still widely open, thus, the impact of urban expansion and urban form on sustainability could be explained from the perspective of social economic aspects.

Author Contributions: Initial research idea, A.J.; conceptualization of the research idea, A.J., E.R., and D.O.P.; data curation, A.J., E.R., and D.O.P.; field survey and observation, A.J.; methodology, A.J., E.R., and D.O.P.; formal analysis, A.J.; visualization of data and analysis result, A.J.; validation, A.J.; writing-original draft preparation, A.J.; writing-review and editing, E.R. and D.O.P.; supervision, E.R. and D.O.P. All authors have read and agreed to the published version of the manuscript.

Funding: This research was funded by PMDSU Scholarship from Ministry of Research and Technology/National Research and Innovation Agency of Republic Indonesia.

Conflicts of Interest: The authors declare no conflict of interest. The funders had no role in the design of the study; in the collection, analyses, or interpretation of data; in the writing of the manuscript, or in the decision to publish the results.

\section{References}

1. McGee, T.; Greenberg, C. The Emergence of Extended Metropolitan Regions in ASEAN. ASEAN Econ. Bull. 1992, 9, 10-34. [CrossRef] [PubMed]

2. Dorodjatoen, A.M. The Emergence of Jakarta-Bandung Mega-Urban Region and Its Future Challenges. J. Perenc. Wil. Dan Kota 2009, 20, 15-33. 
3. McGee, T. The Emergence of Desakota Regions in Asia: Expanding a Hypothesis. Ext. Metrop. Settl. Transit. Asia 1991, 12, 3-25.

4. Rustiadi, E.; Mizuno, K.; Kobayashi, S. Measuring Spatial Pattern of the Suburbanization Process. A Study Case of Bekasi District, Indonesia. J. Rural Plan. Assoc. 1999, 18, 31-42. [CrossRef]

5. Curran-Cournane, F.; Cain, T.; Greenhalgh, S. Attitudes of a Farming Community towards Urban Growth and Rural Fragmentation-An Auckland Case Study. Land Use Policy 2016, 58, 241-250. [CrossRef]

6. Sinha, S.K. Causes of Urban Sprawl: A comparative study of Developed and Developing World Cities. Res. Rev. Int. J. Multidiscip. 2018, 3, 1-5.

7. Ramachandra, T.; Bharath, H.; Vinay, S.; Joshi, N.; Kumar, N.; Venugopal, R. Modelling Urban Revolution in Greater Bangalore, India. In Proceedings of the 30th Annual In-House Symposium on Space Science and Technology, Bangalore, India, 7-8 November 2013; Space Technology Cell, Indian Institute of Science: Bangalore, India, 2013.

8. Sorensen, A.; Okata, J. Megacities: Urban Form, Governance, and Sustainability; Springer: Tokyo, Japan, 2011.

9. Yokohari, M.; Takeuchi, K.; Watanabe, T.; Yokota, S. Beyond greenbelts and zoning: A new planning concept for the environment of Asian mega-cities. Landsc. Urban Plan. 2000, 47, 159-171. [CrossRef]

10. Milojevic, B. Urban Development and Influential Factors on Urban form of Towns in Bosnia and Herzegovinan the Period of Socialism and Transition (Case Study of Banjaluka and Trebinje). Facta Univ. Archit. Civ. Eng. 2013, 11, 237-249. [CrossRef]

11. Varkey, A.M.; Manasi, S. A Review of Peri-Urban Definitions, Land Use Changes and Challenges to Development. Urban India 2019, 39, 96-111.

12. Milder, J. Sustainable Urban Form. In Sustainable Urban Environments; van Bueren, E., van Bohemen, H., Itard, L., Visscher, H., Eds.; Springer: Dordrecht, The Netherland, 2011.

13. Rustiadi, E.; Kobayashi, S. Contiguous Spatial Classification: A New Approach on Quantitative Zoning Method. J. Geogr. Educ. 2000, 43, 122-136.

14. Sabatini, M.C.; Verdiel, A.; Rodriguez, R.M.; Vidal, I.M. A Quantitative Method for Zoning of Protected Areas and its Spatial Ecological Implications. J. Environ. Manag. 2007, 83, 198-206. [CrossRef] [PubMed]

15. Firman, T. The continuity and change in mega-urbanization in Indonesia: A Survey of Jakarta-Bandung Region (JBR) development. Habitat Int. 2009, 33, 327-339. [CrossRef]

16. Winarso, H.; Hudalah, D.; Firman, T. Peri-urban transformation in the Jakarta metropolitan area. Habitat Int. 2015, 49, 221-229. [CrossRef]

17. Fitriani, R. The Extent of Sparwl in the Fringe of Jakarta Metropolitan Area from the Perspective of Externalities. In Proceedings of the 55th Annlual Australian Agricultural and Resource Economics Society Conference, Melbourne, Australia, 8-11 February 2011; University of Sydney: Sydney, Australia, 2011.

18. Hudalah, D.; Firman, T. Beyond Property: Industrial Estates and Post-Suburban Transformation in Jakarta Metropolitan Region. Cities 2012, 29, 40-48. [CrossRef]

19. Pribadi, D.O.; Pauleit, S. Peri-Urban Agriculture in Jabodetabek Metropolitan Area and Its Relationship with the Urban Socioeconomic System. Land Use Policy 2016, 55, 265-274. [CrossRef]

20. Cianjur Regency Government. Cianjur Regency Spatial Planning 2011-2031; Cianjur Regency Development Planning Agency: Cianjur, Indonesia, 2012.

21. West Java Government. West Java Spatial Planning 2009-2029; West Java Development Planning Agency: Bandung, Indonesia, 2010.

22. Douglass, M. Mega-Urban Regions and World City Formation: Globalisation, the Economic Crisis and Urban Policy Issues in Pacific Asia. Urban Stud. 2000, 37, 231-245. [CrossRef]

23. Marinescu, I.E.; Ayram, S. Evaluation of Urban Fragmentation in Craiova City, Romania. Landsc. Environ. Eur. Identity 2012, 14, 207-215. [CrossRef]

24. Bharath, H.; Chandan, M.; Vinay, S.; Ramachandra, T. Modelling Urban Dynamics in Rapidly Urbanising Indian Cities. Egypt. J. Remote Sens. Space Sci. 2018, 21, 201-210. [CrossRef]

25. Bhatta, B. Analysis of Urban Growth and Sprawl from Remote Sensing Data; Springer Science \& Business Media: Berlin, Germany, 2010.

26. Anthony, A.F.; Offia, I.E.; Abidemi, B.R.; Kamoru, O.K.G. Urban Sustainability Concepts and Their Implications on Urban Form. Urban Reg. Plan. 2018, 3, 27-33. [CrossRef]

27. Mahtta, R.; Mahendra, A.; Seto, K.C. Building up or spreading out? Typologies of urban growth across 478 cities of 1 million+. Environ. Res. Lett. 2019, 14, 124077. [CrossRef] 
28. Kin, B.; Verlinde, S.; Macharis, C. Sustainable urban freight transport in megacities in emerging markets. Sustain. Cities Soc. 2017, 32, 31-41. [CrossRef]

29. Tan, M. Uneven growth of urban clusters in megaregions and its policy implications for new urbanization in China. Land Use Policy 2017, 66, 72-79. [CrossRef]

30. He, D.; Sun, Z.; Gao, P. Development of Economic Integration in the Central Yangtze River Megaregion from the Perspective of Urban Network Evolution. Sustainability 2019, 11, 5401. [CrossRef]

31. Tran, T.N.Q.; Fanny, Q.; Claude, M.; Vinh, N.Q.; Nam, L.V.; Truong, T.H. Trends of Urbanization and Suburbanization in Southeast Asia; Ho Chi Minh City General Publishing House: Ho Chi Minh, Vietnam, 2012.

32. Xu, G.; Dong, T.; Cobbinah, P.B.; Jiao, L.; Sumari, N.S.; Chai, B.; Liu, Y. Urban Expansion and form Changes across African Cities with a Global Outlook: Spatiotemporal Analysis of Urban Land Densities. J. Clean. Prod. 2019, 224, 802-810. [CrossRef]

33. Kim, K.J.; Choe, S.C. In Search of Sustainable Urban Form for Seoul. In Megacities: Urban Form, Governance, and Sustainability; Dalam Sorensen, A., Okata, J., Eds.; Springer: Tokyo, Japan, 2011.

34. Okazawa, Y.; Murakami, N. Case Study on Managing Urban Expansion in Tokyo; World Bank Group: Tokyo, Japan, 2017.

35. Perez, J.; Araldi, A.; Fusco, G.; Fuse, T. The Character of Urban Japan: Overview of Osaka-Kobe's Cityscapes. Urban Sci. 2019, 3, 105. [CrossRef]

36. Firman, T.; Fahmi, F.Z. The Privatization of Metropolitan Jakarta's (Jabodetabek) Urban Fringes: The Early Stages of "Post-Suburbanization" in Indonesia. J. Am. Plan. Assoc. 2017, 83, 68-79. [CrossRef]

37. Talitha, T.; Firman, T.; Hudalah, D. Welcoming two decades of decentralization in Indonesia: A regional development perspective. Territ. Politics Gov. 2019, 7, 1-19. [CrossRef]

38. Cianjur Regency Statistical Bureau. Cianjur Regency in Figures 2020; Cianjur Regency Statistical Bureau: Cianjur, Indonesia, 2020.

39. Silva, E.A.; Acheampong, R.A. Developing an Inventory and Typology of Land-Use Planning Systems and Policy Instruments in OECD Countries. OECD Environ. Work. Pap. 2015, 94, 1-52.

40. Starikova, T.V. The regional typology development in the system of strategic planning. J. Ind. Econ. 2017, 10, 172-180. [CrossRef]

41. Housley, J.L. Megacity Analysis: A Clustering Approach to Classification. Master's Thesis, Naval Postgraduate School, Monterey, CA, USA, 2017.

42. Fang, C.; Yu, D. Urban agglomeration: An evolving concept of an emerging phenomenon. Landsc. Urban Plan. 2017, 162, 126-136. [CrossRef]

43. Rodrigue, J.P. Freight, Gateways and Mega-Urban Regions: The Logistical Integration of the Bostwash Corridor. Tijdschr. Econ. Soc. Geogr. 2004, 95, 147-161. [CrossRef]

44. Tan, P.N.; Steinbach, M.; Karpatne, A.; Kumar, V. Introduction to Data Mining; Pearson: Dearborn, MI, USA, 2013.

45. Mulyana, W. Rural-Urban Linkages: Indonesia Case Study. In Working Paper Series RIMISP Document No. 126 Working Group: Development with Territorial Cohesion; Rimisp: Santiago, Chile, 2014.

46. Budiyantini, Y.; Pratiwi, V. Peri-urban typology of Bandung Metropolitan Area. Procedia Soc. Behav. Sci. 2016, 227, 833-837. [CrossRef]

47. McGarigal, K.; Marks, B.J. FRAGSTATS: Spatial Pattern Analysis Program for Quantifying Landscape Structure; United States Department of Agriculture: Corvalis, OR, USA, 1995.

48. Gustafson, E.J. Quantifying Landscape Spatial Pattern: What Is the State of the Art. Us For. Serv. 1998, 1, 143-156. [CrossRef]

49. Debbage, N.A. Quantifying Urban Form via Spatial Metrics and Its Climatic Implication; The University of Georgia: Athens, GA, USA, 2012.

50. Brody, S.D.; Kim, H.; Gunn, J. The Effect of Urban Form on Flood Damage along the Gulf of Mexico Coast. J. Am. Plan. Assoc. 2013, 5, 289-306.

51. Magidi, J.; Ahmed, F. Assessing Urban Sprawl Using Remote Sensing and Landscape Metrics: A Case Study of City of Tshwane, South Africa. Egypt. J. Remote Sens. Space Sci. 2018, 21, 241-253.

52. Dempsey, N.; Brown, C.; Raman, S.; Porta, S.; Jenks, M.; Jones, C.; Bramley, G. Elements of Urban Forms. In Dimensions of the Sustainable Cities; Dalam Jenks, M., Jones, C., Eds.; Springer: London, UK, 2010; pp. $21-51$.

53. Xu, Q.; Zheng, X.; Zhang, C. Quantitative Analysis of the Determinants Influencing Urban Expansion: A Case Study in Beijing, China. Sustainability 2018, 10, 1630. [CrossRef] 
54. Wheeler, S. Regions, Megaregions, and Sustainability. Reg. Stud. 2009, 43, 863-876. [CrossRef]

55. Wheeler, S.M. The Evolution of Urban Form in Portland and Toronto: Implications for sustainability planning. Local Environ. Int. J. Justice Sustain. 2010, 8, 317-336. [CrossRef]

56. Schneider, A.; Woodcock, C.E. Compact, Dispersed, Fragmented, Extensive? A Comparison of Urban Growth in Twenty-five Global Cities Using Remotely Sensed Data, Pattern Metrics and Census Information. Urban Stud. 2008, 45, 659-692. [CrossRef]

57. Mukhopadhyay, C. Megaregions: Globalization's New Urban Form? Eur. Plan. Stud. 2016, 24, 420-422. [CrossRef]

58. Rodrigue, J.P.; Comtois, C.; Slack, B. The Geography of Transport System, 3rd ed.; Routledge: New York, NY, USA, 2013.

59. Lowry, J.H.; Lowry, M.B. Comparing spatial metrics that quantify urban form. Comput. Environ. Urban Syst. 2014, 44, 59-67. [CrossRef]

60. Clarke, K.C.; Gaydos, L.J. Loose-coupling a cellular automaton model and GIS: Long-term urban growth prediction for San Francisco and Washington/Baltimore. Int. J. Geogr. Inf. Sci. 1998, 12, 699-714. [CrossRef] [PubMed]

61. Forman, R.T. Land Mosaics: The Ecology of Landscapes and Regions; Cambridge University Press: Cambridge, UK, 1995.

62. Echenique, M.H.; Hargreaves, A.J.; Mitchell, G.; Namdeo, A. Growing Cities Sustainably. J. Am. Plan. Assoc. 2012, 78, 121-137. [CrossRef]

63. Kawakami, M.; Shen, Z.; Pai, J.T.; Gao, X.S.; Zhang, M. Spatial Planning and Sustainable Development: Approaches for Achieving Sustainable Urban Form in Asian Cities; Springer: New York, NY, USA, 2013.

64. Liu, Y.; Peter, H.; Song, X. Research on the relationship between urban form and urban smog in China. Environ. Plan. B Urban Anal. City Sci. 2017, 44, 328-342. [CrossRef]

65. Dandekar, H.C. Qualitative Methods in Planning Research and Practice. J. Arch. Plan. Res. 2005, 22, $129-137$.

66. Coman, A.; Munoz-Avila, H. Qualitative vs. Quantitative Plan Diversity in Case-Based Planning. In Integration of Sequence Learning and CBR for Complex Equipment Failure Prediction; Compta, M., Lopez, B., Eds.; Springer: Girona, Spain, 2011.

67. Groff, S.P.; Rau, S. China's City Clusters: Pioneering Future Mega-Urban Governance. Am. Aff. 2019, 3, 134-150.

68. Bathelt, H.; Zhao, J. Conceptualizing multiple clusters in mega-city regions: The case of the biomedical industry in Beijing. Geoforum 2016, 75, 186-198. [CrossRef]

69. Fu, Y.; Zhang, X. Mega urban agglomeration in the transformation era: Evolving theories, research typologies and governance. Cities 2020, 105, 102813. [CrossRef]

70. International Transport Forum (ITF). Connectivity and City Clusters; OECD Publishing: Paris, France, 2018.

71. Aguilar, A.G.; Ward, P. Globalization, Regional Development, and Mega-City Expansion in Latin America: Analyzing Mexico City's Peri-Urban Hinterland. Cities 2003, 20, 3-21. [CrossRef]

72. Sassi, E.; Benabdelhafid, A.; Hammami, S. A Methodological Approach of a Hinterland Planning Project Decision Support. Int. J. Traffic Transp. Eng. 2019, 8, 59-71.

(C) 2020 by the authors. Licensee MDPI, Basel, Switzerland. This article is an open access article distributed under the terms and conditions of the Creative Commons Attribution (CC BY) license (http://creativecommons.org/licenses/by/4.0/). 